East African Medical Journal Vol. 86. No. 3 March 2009

GINGIVAL RECESSION, ORAL HYGIENE AND ASSOCIATED FACTORS AMONG TANZANIAN WOMEN

E. G. S. Mumghamba, DDS, MDent, Senior Lecturer, Department of Restorative Dentistry, School of Dentistry, Muhimbili University of Health and Allied Sciences, P. O Box 65014, Dar es Salaam, Tanzania, S. Honkala, DDS, MSc, Dr. Odont., Docent, E. Honkala, DDS, DDPH, MSc, Dr. Odont., Professor, Department of Community Dentistry, Institute of Dentistry, University of Turku, Finland, and K.P. Manji, MD, MMed, MPH, Professor, Department of Paediatrics and Child Health, School of Medicine, Muhimbili University of Health and Allied Sciences, P.O Box 65001, Dar es Salaam, Tanzania

Request for reprints to: Dr. E. G. S. Mumghamba, Department of Restorative Dentistry, School of Dentistry, Muhimbili University of Health and Allied Sciences, P. O Box 65014, Dar es Salaam, Tanzania

\title{
GINGIVAL RECESSION, ORAL HYGIENE AND ASSOCIATED FACTORS AMONG TANZANIAN WOMEN
}

\author{
E. G. S. MUMGHAMBA, S. HONKALA, E. HONKALA and K.P. MANJI
}

\begin{abstract}
Background: Females are generally more motivated with regard to oral hygiene practices and thus brush their teeth more frequently than males.

Objective: To determine the prevalence of gingival recession, oral hygiene status, oral hygiene practices and associated factors in women attending a maternity ward in Tanzania.

Design: Cross-sectional descriptive study.

Setting: Maternity ward of Muhimbili National Hospital, Tanzania.

Subjects: Four hundred and forty six women were interviewed on oral hygiene practices and maternal factors, and a full-mouth examination was done to determine the presence of plaque, calculus, gingival bleeding and gingival recession at six sites per tooth.

Results: The prevalence of gingival recession (GR) $\geq 1 \mathrm{~mm}$ was $33.6 \%$, calculus $99.3 \%$, plaque $100 \%$, and gingival bleeding $100 \%$. Oral hygiene practices included toothbrushing $(98.9 \%)$, brushing frequency $\geq 2$ times/day $(61.2 \%)$, horizontal brushing method $(98 \%)$, and using a plastic toothbrush $(\mathbf{9 7 . 8} \%)$. Factors that were significantly associated with gingival recession were age $\left(\mathrm{OR}^{\mathrm{a}}=2.0,95 \% \mathrm{CI}=1.3-3.2\right)$, presence of calculus $\left(\mathrm{OR}^{\mathrm{a}}=3.8,95 \% \mathrm{CI}=2.5-7.1\right)$, and gingival bleeding on probing $(\mathrm{OR}=4.2,95 \% \mathrm{CI}=2.5-7.1)$. Tooth cleaning practices and maternal factors, especially the number of pregnancies or deliveries were not significantly associated with gingival recession.

Conclusion: In this study population, oral hygiene was poor and gingival recession was associated with age, calculus and gingival inflammation rather than with tooth cleaning practices.
\end{abstract}

\section{INTRODUCTION}

The occurrence of gingival recession in young adults as well as in the elderly population in Tanzania varies between $13-72 \%$ (1-3). Previous epidemiological studies in Tanzania have shown that the oral hygiene standard of the population was generally poor with the occurrence of dental plaque as high as $99.6 \%$ and that of dental calculus being $75-100 \%$ (24). Tooth cleaning devices commonly used include plastic toothbrushes (52-68\%), chewing sticks (26-32\%), both plastic toothbrushes as well as chewing sticks $(17.0 \%)$, and dental floss $(1 \%)(3,5,6)$. Most of the rural population that constitutes about $85 \%$ of the general population in Tanzania uses chewing sticks rather than the toothbrush $(3,6)$. While the use of chewing sticks among school children under proper instruction has been reported to be as effective as plastic toothbrushes for control of plaque and gingival bleeding (7), the traditional, unsupervised method of tooth cleaning had no significant effect on plaque control among either children or adults $(6,8)$.

The purpose of using tooth cleaning devises is to attain good oral hygiene compatible with good oral health. Unfortunately, the practice when not performed appropriately, may result into unwanted ill effects such as recession of the gingival tissues, trauma to soft tissues and abrasion of dental hard tissues (9). Females are generally more motivated with regard to oral hygiene practices and thus brush their teeth more frequently than males $(5,6)$. The 
prevalence and extent of unwanted ill effects of oral hygiene practices among Tanzanian women are not known. Therefore, the purpose of the present study was to determine the prevalence of gingival recession, level of oral hygiene, oral hygiene practices and associated factors among women at a maternity ward at Muhimbili National Hospital, Tanzania.

\section{MATERIALS AND METHODS}

Study area and participants: This cross-sectional descriptive study involved women who were readily available after delivery between August 2002 and January 2003 in a public university teaching hospital setting, the Muhimbili National Hospital. Tanzania has an estimated total population of 39.5 million people; with a life expectancy of 53 years for females (10). The Gross Domestic Product (GDP) per capita was 350 USD; $89.9 \%$ of the general population living on less than 2 USD per day and adult illiteracy rate for women being $38 \%$ (10). The country has an estimated dentist population ratio of $1: 220,000$. The estimated sample size $(n=457)$ for the present study was based on the prevalence rate of gingival recession ( $30 \%$ ) and the difference between the groups according to oral hygiene (poor / good $=$ $5 \% / 15 \%)$. The power of the study was $90 \%$ with an alpha level of 0.05 (2-sided Chi-square test). The objectives of the study were explained to the sampled population, and those who were willing to participate and gave their written consent were recruited for the study.

Interview and clinical examination: The study participants were first interviewed using a structured questionnaire followed by a clinical intra-oral examination. The questionnaire consisted of questions on demographic data (age, level of education, and marital status), oral hygiene practices (toothbrushing practice, time of brushing, flossing, use of tooth picks), tooth cleaning devices used (plastic toothbrush and chewing stick or miswak), tobacco smoking, history of gum bleeding on toothbrushing, consumption of coffee and intake of alcohol.

In the clinical examination, all teeth were examined (including the third molars) and scored for all six surfaces of the teeth (bucco-mesial, mid-buccal, bucco-distal, lingual-mesial, midlingual and lingual-distal). The mean number of teeth examined per person was 30.2 \pm 1 .9. Gingival recession was scored in absolute numbers using the Williams periodontal probe marked at 1,2,3,5,7,9, and $10 \mathrm{~mm}$ (11). Dichotomous scoring (present or absent) was used for dental plaque, calculus, and gingival bleeding on gentle probing. Dental plaque was scored as present if it was visible on the end of the probe after running the Williams periodontal probe over the tooth surface. Through tactile sensation, the Community Periodontal Index (CPI) clinical probe with a bulb tip diameter of $0.5 \mathrm{~mm}$ (12), was used to examine calculus and gingival bleeding on gentle probing whereby each condition was recorded separately. Blood pressure and obstetric history, in particular number of pregnancies and deliveries were also obtained from medical records. One calibrated examiner performed all the clinical examinations; and during data collection, duplicate clinical examinations were made for thirty six study participants $(8 \%)$. Using a Kappa test, the reproducibility (kappa value \pm standard error and the $95 \%$ confidence interval) for gingival recession was $0.78 \pm 0.01$ (0.76-0.81) and the level of significance test was $\mathrm{p}<0.00$ I. For gingival bleeding and microbial plaque, reproducibility was not scored because for these conditions it was not practical to repeat the examination on the same day.

Inclusion and exclusion criteria: Mothers who had just given birth or were being admitted with a newborn at the hospital qualified to be included in the study, except for those known to have underlying systemic diseases. Exclusion criteria included all those mothers who had on their medical records diabetes mellitus, heart disease, kidney diseases, HIV/AIDS, genitourinary tract infection, or other infections or conditions that needed concurrent antibiotic therapy. Screening for HIV was not performed. The number of teeth remaining and periodontal therapy were not considered as important factors for inclusion/ exclusion criteria as in this study population the minimum number of teeth present was twenty three, and none of the participants had ever attended periodontal therapy before the study.

Ethical considerations: The Ethical Committee of Muhimbili University College of Health Sciences (MUCHS) approved the study, which was conducted in accordance with the Helsinki Declaration.

Data analysis: Data were entered into a personal computer and analysed using the Statistical Package for Social Sciences (SPSS) 13.0. Skewed data was analysed using Spearman's correlation test that employed "rank-system". The relationship between gingival recession and other variables was studied using the multivariate logistic regression (MLR), and the level of significance was set at $\mathrm{p}<0.05$.

\section{RESULTS}

The study population included 446 Tanzanian African women aged 14 to 44 years (mean age = $23.4 \pm 5.4$ years). Age distribution according to the level of education is shown in Table 1. 


\section{Table 1}

Distribution of study participants by age groups and level of education

\begin{tabular}{|c|c|c|c|c|}
\hline \multirow{2}{*}{$\begin{array}{l}\text { Age group } \\
\text { (years) }\end{array}$} & \multirow[t]{2}{*}{ No. of participants } & \multicolumn{2}{|c|}{ Level of education $(\%)$} & All $(\%)$ \\
\hline & & Informal to primary & Secondary to college & \\
\hline 14-19 & 126 & 93.7 & 6.3 & 28.0 \\
\hline $20-24$ & 155 & 87.7 & 12.3 & 35.0 \\
\hline $25-29$ & 107 & 78.5 & 21.5 & 24.0 \\
\hline $30-44$ & 58 & 75.9 & 24.1 & 13.0 \\
\hline Total & 446 & 85.7 & 14.3 & 100 \\
\hline
\end{tabular}

Gingival recession according to jaw and tooth type: All 446 study participants were clinically examined and the number of teeth presented varied between 23 and 32 per person (mean $=30.2 \pm 1.9$ (standard deviation, $\mathrm{Sd}$ ), whereas $83.2 \%$ of the participants had one to four third molars in place. The prevalence of gingival recessions (GR) $\geq 1$ $\mathrm{mm}$ among all study participants was $33.6 \%$, the mean number of sites affected was $1.5 \pm 3.3$. Based on the total number of surfaces affected, the extent of gingival recession was $2.7 \%$. The differences in the mean number of teeth examined among the GR $(30.1 \pm 1.9)$ were not statistically significant. In the whole study population, there were only four active tobacco smokers $(0.9 \%)$. In bivariate analysis none of the active tobacco smokers had gingival recession. The occurrence of gingival recession in percentages of the surfaces affected per jaw and tooth type is shown in Table 2.
Due to the fact that some of the tooth surfaces had been destroyed by caries and thus could not be available for assessment, the number of buccal and lingual surfaces is not necessarily equal in number. Generally, GR affected more of the mandibular teeth $(4.3 \%)$ than the maxillary teeth $(1.1 \%)$. On the lower teeth the lingual surfaces were more affected $(5.9 \%)$ than the buccal surfaces $(1.1 \%)$ and by tooth type; incisors and canines were more affected $(9.6 \%)$ than the premolars $(0.8 \%)$ or molars $(0.7 \%)$.

Dental plaque, calculus and oral hygiene standards: Among the 446 study participants, the prevalence of plaque was $100 \%$ and that of dental calculus was $99.3 \%$. The percentage of surfaces with plaque was $76.8 \%$ and calculus $(25.9 \%)$, whereas the mean number of surfaces affected was $131.6 \pm 28.8$ and $44.3 \pm 32.5$, respectively. Compared to those with secondary or higher education, the participants

Table 2

The occurrence of gingival recession in percentages of the surfaces affected per jaw-and tooth-type

\begin{tabular}{|c|c|c|c|c|c|c|c|}
\hline \multirow[t]{2}{*}{ Tooth type } & \multirow[b]{2}{*}{ Buccal } & \multicolumn{2}{|c|}{$\begin{array}{c}\text { Maxillary (upper) tooth } \\
\text { surfaces }\end{array}$} & \multicolumn{4}{|c|}{$\begin{array}{c}\text { Mandibular (lower) tooth } \\
\text { surfaces }\end{array}$} \\
\hline & & Palatal & $\begin{array}{c}\text { All } \\
\text { Maxillary }\end{array}$ & Lingual & Buccal & $\begin{array}{c}\text { All } \\
\text { Mandibular }\end{array}$ & All \\
\hline Incisors and canines & 1.4 & 0.2 & 0.8 & 13.6 & 5.5 & 9.6 & 5.2 \\
\hline Premolars & 1.1 & 0.4 & 0.9 & 0.5 & 0.7 & 0.6 & 0.8 \\
\hline Molars & 2.0 & 1.1 & 1.5 & 0.5 & 0.9 & 0.6 & 1.0 \\
\hline All & 1.6 & 0.5 & 1.1 & 5.9 & 1.1 & 4.3 & 2.7 \\
\hline
\end{tabular}

Table 3

Level of oral hygiene standard in percentages of sites free of dental plaque and the occurrence of gingival

\begin{tabular}{|c|c|c|c|}
\hline \multirow{2}{*}{$\begin{array}{l}\text { Level of OHS (\% of tooth } \\
\text { surfaces free of dental } \\
\text { plaque) }\end{array}$} & \multicolumn{2}{|c|}{$\begin{array}{c}\text { Number of persons with } \\
\text { gingival recession }\end{array}$} & \multirow{2}{*}{$\begin{array}{c}\text { Total } \\
\text { No. }(\%)\end{array}$} \\
\hline & $\begin{array}{c}\text { Yes } \\
\text { No. }(\%) \\
\end{array}$ & $\begin{array}{c}\text { No } \\
\text { No. }(\%) \\
\end{array}$ & \\
\hline Very good (81-100\%) & - & - & - \\
\hline Good $(61-80 \%)$ & 21.3 & 144.7 & 163.6 \\
\hline Satisfactory (41-60\%) & 74.7 & 4414.9 & 5111.4 \\
\hline Poor $(21-40 \%)$ & 5436.0 & 13244.6 & 18641.7 \\
\hline Very poor $(0-20 \%)$ & $87 \quad 58.0$ & 10635.8 & 19343.3 \\
\hline Total & 150100 & 296100 & 446100 \\
\hline
\end{tabular}


with primary education or less had significantly higher percentages of surfaces with plaque ( $\mathrm{p}<$ $0.001)$ and dental calculus $(\mathrm{p}=0.039)$. According to the operational categorisation of oral hygiene standard (OHS), most of the study participants had poor $(41.7 \%)$ or very poor $(43.3 \%)$ oral hygiene (Table 3). None of the participants was classified as having very good OHS. The group of participants who had gingival recession was composed of a significantly higher proportion of individuals with very poor oral hygiene $(58.0 \%)$ compared to those who had no gingival recession $(35.8 \%)(\mathrm{p}<0.001)$.

Toothbrushing practices: A majority (98.7\%) of the participants practised toothbrushing but only $1.3 \%$ used mouth rinsing. Most of the women $(97.8 \%)$ used a plastic toothbrush, and very few used chewing sticks (0.9\%). Toothbrushing was done mostly before breakfast $(99.6 \%)$ and less often before going to bed (39\%); using horizontal scrubbing $(98 \%)$ and vertical methods $(2.0 \%)$. Frequency of toothbrushing was 1-5 times per day (mean 1.72 \pm 0.67 ), where regular toothbrushing frequency once a day was $38.8 \%$, twice a day only $51.1 \%$, two times a day or more $61.2 \%$, three times a day $9.2 \%$. The proportion of participants who brushed twice or more a day was higher among those who had secondary education and above (79.2\%) than among those with primary education $(58.1 \%, \mathrm{p}=0.001)$. For inter-dental cleaning, toothpicks were used by $99.4 \%$ and dental floss by $0.6 \%$. Most of the study participants used toothpaste $(93.7 \%)$, and the rest used salt $(1.3 \%)$, charcoal/ash $(0.8 \%)$ or just water(4.8\%).

Mean gingival recession sites in relation to sites with plaque, calculus and other factors: The mean number of sites with gingival recessions in relation to a specific "median or other split value" for plaque, calculus, gingival bleeding on gentle probing, level of education, toothbrushing frequency and maternal factors are shown in Table 4. The study participants who had values "higher than or equal to" the median split value (Yes category compared to those who had "lower" values (No category), showed higher mean numbers of surfaces with gingival recession in association with plaque $(\mathrm{p}=0.036)$ and calculus $(\mathrm{p}=0.001)$, respectively). Using percentages of surfaces affected, gingival recession was positively associated (Spearman's Rho correlation) with the presence of plaque (0.3), calculus (0.5), gingival bleeding (0.5), and age (0.2). For all factors this association was statistically significant $(\mathrm{p}=0.01)$. A strong and positive association (0.7) was found between calculus and gingival bleeding on probing $(\mathrm{p}<0.01)$.

Table 4

Mean number of sites with gingival recessions in relation to a specific "median or other split value" for each selected condition

\begin{tabular}{|c|c|c|c|c|c|}
\hline \multirow[t]{2}{*}{$\begin{array}{l}\text { Dichotomised conditions based on } \\
\text { median split value }\end{array}$} & \multirow{2}{*}{$\begin{array}{l}\text { Number of } \\
\text { study } \\
\text { participants } \\
\text { (n) }\end{array}$} & \multirow{2}{*}{$\begin{array}{l}\text { Occurrence } \\
\text { of gingival } \\
\text { recessions } \\
\text { (sites) } \\
\text { Mean (Sd) }\end{array}$} & \multicolumn{2}{|c|}{$\begin{array}{l}95 \% \text { confidence } \\
\text { interval }(95 \% \mathrm{CI}) \\
\text { of the difference }\end{array}$} & \multirow[t]{2}{*}{$\begin{array}{l}\text { T-test } \\
\text { P-value }\end{array}$} \\
\hline & & & Lower & Upper & \\
\hline \multirow[t]{2}{*}{ Plaque ( $\geq 133^{*}$ surfaces) } & Yes $(\mathrm{n}=217)$ & $1.9(2.8)$ & & & \\
\hline & No $(n=229)$ & $1.2(3.7)$ & 0.04 & 1.27 & 0.036 \\
\hline \multirow[t]{2}{*}{ Calculus ( $\geq 38^{*}$ surfaces) } & Yes $(n=221)$ & $2.4(3.6)$ & & & \\
\hline & $\mathrm{No}(\mathrm{n}=225)$ & $0.6(2.8)$ & 1.22 & 2.41 & $<0.001$ \\
\hline \multirow{2}{*}{ Gingival bleeding ( $\geq 73^{*}$ surfaces) } & Yes $(n=225)$ & $0.6(2.6)$ & & & \\
\hline & No $(n=221)$ & $2.5(3.7)$ & -2.47 & -1.28 & $<0.001$ \\
\hline \multirow[t]{2}{*}{ Age ( $>22^{*}$ years $)$} & Yes $(n=221)$ & $2.0(3.8)$ & & & \\
\hline & No $(n=225)$ & $1.1(2.7)$ & 0.28 & 1.51 & $<0.004$ \\
\hline \multirow{4}{*}{$\begin{array}{l}\text { Level of education } \\
\text { ( } \leq \text { primary) } \\
\text { *Toothbrushing frequency }(\geq x 2)\end{array}$} & Yes $(n=382)$ & $1.5(3.0)$ & & & \\
\hline & No $(n=64)$ & $1.9(4.6)$ & -1.66 & 0.79 & 0.480 \\
\hline & Yes $(n=273)$ & $1.6(3.5)$ & & & \\
\hline & No $(n=173)$ & $1.5(3.0)$ & -0.50 & 0.77 & 0.675 \\
\hline \multirow{4}{*}{$\begin{array}{l}\text { Number of pregnancies } \\
(\geq 3) \\
\text { Number of deliveries }(\geq 2)\end{array}$} & Yes $(n=120)$ & $2.2(3.8)$ & & & \\
\hline & No $(n=326)$ & $1.3(3.1)$ & 0.10 & 1.60 & 0.026 \\
\hline & Yes $(\mathrm{n}=198)$ & $1.9(3.7)$ & & & \\
\hline & No $(n=248)$ & $1.2(3.0)$ & 0.10 & 1.30 & 0.032 \\
\hline
\end{tabular}

${ }^{*}=$ Median split value, $\mathrm{Sd}=$ Standard deviation 
Occurrence of gingival recession in relation to dental conditions and other maternal factors: Occurrence of gingival recession in relation to a number of dental conditions and other maternal factors (bivariate analysis) without controlling for their effects is shown in Table 5. In the bivariate analysis, significant factors were age $(p<0.01)$, plaque, calculus, and gingival bleeding on probing $(\mathrm{p} \geq 0.001)$. With regard to maternal factors, participants with GR compared to the non-GR group had a higher proportion of women with a history of pregnancies $\geq 3(p=0.016)$ and deliveries $\geq 2(\mathrm{p}=0.036)$.

Table 5

Occurrence of gingival recession in relation to dental conditions and other maternal factors

\begin{tabular}{|c|c|c|c|c|c|c|c|c|}
\hline \multirow[t]{3}{*}{$\begin{array}{l}\text { Factors associated with gingival } \\
\text { recession - present (Yes/ No) }\end{array}$} & & \multicolumn{2}{|c|}{$\begin{array}{l}\text { Number of } \\
\text { participants } \\
\text { (n) }\end{array}$} & \multicolumn{3}{|c|}{$\begin{array}{l}\text { Occurrence Un-adjusted } \\
\text { of gingival } \\
\text { recession }\end{array}$} & \multirow{3}{*}{$\begin{array}{l}\text { Odds Ratio } \\
(95 \% \mathrm{CI})\end{array}$} & \multirow[t]{3}{*}{$\mathrm{p}$-value } \\
\hline & & \multirow{2}{*}{\multicolumn{3}{|c|}{$\begin{array}{l}\text { Yes } \\
\text { No. }(\%)\end{array}$}} & \multicolumn{2}{|c|}{ No } & & \\
\hline & & & & & No. & $(\%)$ & & \\
\hline \multirow{2}{*}{$\begin{array}{l}\text { Age group (14-22 years) } \\
\text { versus (23-44 years) }\end{array}$} & Yes & 225 & 62 & 41.3 & 163 & 55.1 & 0.58 & \\
\hline & No & 221 & 88 & 58.7 & 133 & 44.9 & $(0.39,0.86)$ & 0.006 \\
\hline \multirow[t]{2}{*}{ Marital status: Married } & Yes & 157 & 49 & 32.7 & 108 & 36.5 & 0.85 & \\
\hline & No & 289 & 101 & 67.3 & 188 & 63.5 & $(0.56,1.28)$ & 0.425 \\
\hline \multirow{2}{*}{$\begin{array}{l}\text { Level of education: Primary or } \\
\text { less }\end{array}$} & Yes & 382 & 132 & 88.0 & 250 & 84.5 & 1.35 & \\
\hline & No & 64 & 18 & 12.0 & 46 & 15.5 & $(0.75,2.42)$ & 0.314 \\
\hline \multirow{2}{*}{$\begin{array}{l}\text { Brushing method: Horizontal } \\
\text { versus horizontal rotatory }\end{array}$} & Yes & 327 & 116 & 77.3 & 211 & 71.3 & 1.37 & \\
\hline & No & 119 & 34 & 22.7 & 85 & 28.7 & $(0.87,2.17)$ & 0.212 \\
\hline \multirow{4}{*}{$\begin{array}{l}\text { Frequency of toothbrushing: } \\
\text { two times or more per day } \\
\text { Toothpaste use }\end{array}$} & Yes & 273 & 88 & 58.7 & 185 & 62.5 & 0.85 & \\
\hline & No & 173 & 62 & 41.3 & 111 & 37.5 & $(0.57,1.27)$ & 0.432 \\
\hline & Yes & 418 & 139 & 92.7 & 279 & 94.3 & 0.77 & \\
\hline & No & 28 & 11 & 7.3 & 17 & 5.7 & $(0.35,1.69)$ & 0.513 \\
\hline \multirow{2}{*}{ Tongue brushing } & Yes & 420 & 139 & 92.7 & 281 & 94.9 & 0.68 & \\
\hline & No & 26 & 11 & 7.3 & 15 & 5.1 & $(0.30,1.51)$ & 0.335 \\
\hline \multirow{2}{*}{$\begin{array}{l}\text { Plaque accumulation: } \geq 133 \\
\text { surfaces * }\end{array}$} & Yes & 217 & 99 & 66.0 & 118 & 39.9 & 2.93 & \\
\hline & No & 229 & 51 & 34.0 & 178 & 60.1 & $(1.94,4.41)$ & $<0.001$ \\
\hline \multirow{2}{*}{$\begin{array}{l}\text { Calculus deposits: } \geq 38 \\
\text { surfaces* }\end{array}$} & Yes & 221 & 119 & 79.3 & 102 & 34.5 & 7.30 & \\
\hline & No & 225 & 31 & 20.7 & 194 & 65.5 & $(4.60,11.59)$ & $<0.001$ \\
\hline \multirow{4}{*}{$\begin{array}{l}\text { Gum bleeding on tooth } \\
\text { brushing } \\
\text { Gingival bleeding on probing }\end{array}$} & Yes & 162 & 71 & 47.3 & 91 & 30.7 & 2.03 & \\
\hline & No & 284 & 79 & 52.7 & 205 & 69.3 & $(1.35,3.03)$ & 0.001 \\
\hline & Yes & 221 & 119 & 79.3 & 102 & 34.5 & 7.30 & \\
\hline & No & 225 & 31 & 20.7 & 194 & 65.5 & $(4.60,11.59)$ & $<0.001$ \\
\hline \multirow{2}{*}{$\begin{array}{l}\text { Tobacco smoking (active } \\
\text { smokers) }\end{array}$} & Yes & 4 & 0 & 0.0 & 4 & 1.4 & 1.5 & \\
\hline & No & 442 & 150 & 100 & 292 & 98.6 & $(1.42,1.62)$ & 0.305 \\
\hline \multirow[t]{2}{*}{ Blood pressure $\geq 130 / 90$} & Yes & 51 & 12 & $8.0)$ & 39 & 13.2 & 0.57 & \\
\hline & No & 395 & 138 & 92.0 & 257 & 86.8 & $(0.29,1.13)$ & 0.105 \\
\hline \multirow[t]{2}{*}{ Number of pregnancies $\geq 3$} & Yes & 120 & 51 & 34.0 & 69 & 23.3 & 1.7 & \\
\hline & No & 326 & 99 & 66.0 & 227 & 76.7 & $(1.1,2.6)$ & 0.016 \\
\hline \multirow[t]{2}{*}{ Number of deliveries $\geq 2$} & Yes & 198 & 77 & 51.3 & 121 & 40.9 & 1.5 & \\
\hline & No & 248 & 73 & 48.7 & 175 & 59.1 & $(1.0,2.3)$ & 0.036 \\
\hline \multirow[t]{2}{*}{ Malaria fever } & Yes & 253 & 87 & 58.0 & 166 & 56.1 & 1.08 & \\
\hline & No & 193 & 63 & 42.0 & 130 & 43.9 & $(0.73,1.61)$ & 0.699 \\
\hline \multirow[t]{2}{*}{ Visit to a dental clinic } & Yes & 15 & 7 & 4.7 & 8 & 2.7 & 1.76 & \\
\hline & No & 431 & 143 & 95.3 & 288 & 97.3 & $(0.63,4.96)$ & 0.277 \\
\hline \multirow[t]{2}{*}{ Alcohol use } & Yes & 66 & 20 & 13.3 & 46 & 15.5 & 0.84 & \\
\hline & No & 380 & 130 & 86.7 & 250 & 84.5 & $(0.48,1.47)$ & 0.535 \\
\hline \multirow[t]{2}{*}{ Coffee use } & Yes & 68 & 26 & 17.3 & 42 & 14.2 & 1.27 & \\
\hline & No & 378 & 124 & 82.7 & 254 & 85.8 & $(0.74,2.16)$ & 0.383 \\
\hline
\end{tabular}

*=Median split value 
Multivariate logistic regression analysis: The factors that were expected to have been more associated with gingival recession because of the statistically significant value given in the bivariate analysis were included in the "MLR" analysis. These factors included the age of the participant, plaque, calculus, gingival bleeding on probing, gingival bleeding on toothbrushing, number of pregnancies and deliveries. The final "MLR" model in the Backward (Wald) Stepwise method, with both un-adjusted and adjusted Odds ratios, is shown in Table 6 . In this study population, the factors that were most likely associated with the occurrence of gingival recession were age $\left(\mathrm{OR}^{\mathrm{a}}=2.0,95 \% \mathrm{CI}=1.3\right.$ $3.2, \mathrm{p}=0.003)$, calculus $(\mathrm{OR}=3.8,95 \% \quad \mathrm{CI}=2.5$ 7.1, $\mathrm{p}<0.00 \mathrm{I})$, and gingival bleeding on probing $\left(\mathrm{OR}^{\mathrm{a}}=4.2,95 \% \mathrm{CI}=2.5-7.1, \mathrm{p}<0.001\right)$. The number of pregnancies and deliveries were not significantly associated with gingival recession.

\section{DISCUSSION}

Women have previously been reported to have better oral hygiene than men in Tanzania (5) and elsewhere (13) and women in general have more GR than men do (14). In this study population comprising women only, the prevalence of gingival recession appears to have been lower than that found among non-hispanic blacks in the United States (15). In the present study, gingival recession was found more often on mandibular than on maxillary teeth, which was in agreement with other reports in Tanzania (16), but is contrary to those studies from Turkey, United States and elsewhere $(13,15,17)$. It should be noted that in this study the mean number of teeth examined was not significantly different among participants with or without gingival recession. In general it has been reported that most Tanzanians retain most of their teeth even beyond the age of sixty nine years (18). With regard to sites, gingival recession was detected mainly on the buccal surfaces, a finding that concurs with previous reports (19-21). In mandibular teeth, lingual surfaces were affected more often than buccal surfaces, which is also in agreement with other reports (16). A possible explanation for this might be poor access for proper cleaning of mandibular lingual surfaces and rapid formation of calculus on the lingual sites due to opening of salivary ducts (22). In the premolar areas of the mandibular teeth there was more GR on the buccal than on the lingual surfaces, which is in agreement with studies done on multi-ethnic groups (23). The possible explanation for this might be the root position of the premolars in the more buccal aspects, leading to the high susceptibility to GR (24).

In this study population, the factors that were significantly associated with GR were age, presence of calculus and gingival bleeding. The occurrence of gingival recession correlated with age, which is supported by other findings in Tanzania $(2,16)$ and elsewhere $(14,21,25,26)$. The association between gingival recession and calculus in this study is in agreement with results for other populations in Tanzania $(16,27)$, Brazil (26) and elsewhere (20). The explanation for this is thought to be due to mechanical displacement of the gingival tissue by calculus deposits as well as toxins from both the viable microbial plaque and that which is harboured within the calculus deposit (28). Also in this study, there was an association between gingival recession and gingival bleeding, which was in agreement with other reports $(2,29)$. One could argue that during hospitalisation, the study participants were less efficient in controlling plaque and, therefore, might have affected gingival bleeding and gingival recession, respectively. Since the total time spent at the hospital after admission for most of the study participants did not exceed 40 days in relation to the time of the clinical examination for the plaque and gingival conditions (30), it is considered that this did not affect the results as gingival recession takes years to develop (19). However, the association between gingival bleeding on probing and recession in this study might have been exaggerated because of the tendency for having increased gingival bleeding during pregnancy and after delivery which takes time up to two or three months to resolve $(31,32)$.

In the present study, most of the participants used plastic toothbrushes, few used only chewing sticks and extremely a few used a combination of chewing sticks and plastic toothbrushes. The common use of plastic toothbrushes in this study population might have been considered to have been safer than using chewing sticks which were positively associated with a higher prevalence of gingival recession (25). Irrespective of the type of toothbrush used, most of the participants in this study population employed horizontal scrubbing technique for toothbrushing but surprisingly its effect on the occurrence of gingival recession was not statistically significant, and is contrary to what is commonly found in the literature $(13,17,33)$. Gingival recession has been reported in subjects with both good and poor oral hygiene (21).

Gingival recession resulting from well established, regular oral hygiene practices tends to be more frequent and severe in individuals with clinically healthy gingival tissue, little microbial plaque and good oral hygiene (33). However, this was not the case in the present study. The possible explanation for this discrepancy might have been that in this study population, the horizontal scrubbing tooth brushing technique might have been applied in a different manner that rendered it to be less 
effective, and that is why most of the participants had poor oral hygiene. In the present study, the participants self-reported a high frequency of tooth cleaning practice but on examination most participants had poor oral hygiene yet the two are not expected to be compatible. The reason for this is not known. However, it may be speculated that the participants had inadequate knowledge to perform effective tooth cleaning procedures as it has also been reported that poor skills for toothbrushing were very much evident among primary school teachers (34). In this study, the frequency of toothbrushing did not appear to have been a significant factor for the occurrence of gingival recession and this is in agreement to what has been reported in Jordan (35) and other places (36).

In addition, almost all of the participants in the present study used toothpicks. However, the readily available toothpicks in Tanzania were the cylindrical ones, which when used in intact healthy inter-dental papilla, may cause permanent recession of the papilla $(9,37)$. The triangular toothpicks that are recommended for individuals with open inter-dental spaces were not available. The possible harmful effects on wide use of toothpicks were not investigated as this was not within the scope of the present study. The use of dental floss in this study was very low and this is in agreement with other reports $(3,5,6)$. Tobacco smoking is not a common habit among Tanzanian women and, therefore, the prevalence of smoking in the present study was indeed very low as expected. Due to the very low number of active tobacco smokers the effect of smoking on gingival bleeding could not be substantiated. However, there are reports, generally, showing decreased gingival bleeding tendency on probing among smokers compared to non-smokers (38). Among the limitations worth noting in the present study is the fact that the study was conducted among relatively young women, therefore, the low prevalence of GR was expected since it is known to increase with age.

In conclusion, this study on occurrence of gingival recession was low and was associated with age, presence of calculus and gingival inflammation rather than with tooth cleaning practices since hygiene was very poor despite the high frequency of toothbrushing. The number of pregnancies and deliveries were not significantly associated with gingival recession.

\section{ACKNOWLEDGEMENTS}

This study was funded by the Muhimbili University College of Health Sciences (MUCHS) of the University of Dar es Salaam (UDSM), Dar es Salaam, Tanzania, and Swedish International Development Agency/The Department for Research Cooperation (SIDAISAREC). MUCHS has been upgraded to a full University known as the "Muhimbili University of Health and Allied Sciences" (MUHAS).

\section{REFERENCES}

I. Lembariti, B.S. Periodontal diseases in urban and rural populations in Tanzania. MSc thesis, Dar es Salaam: University of Dar es Salaam, Dar es Salaam; 1983.

2. Mumghamba, E.G.S., Markkanen, H.A. and Honkala, E. Risk factors for periodontal diseases in Ilala, Tanzania. J. Clin. Periodontol. 1995; 5: 347-354.

3. Mumghamba, E.G.S. and Fabian, F.M. Periodontal health status and oral hygiene practices among middle-aged adults in Mtwara rural, Tanzania. Afr. J. Oral. Health Sci. 2003; 4: 192-197.

4. Lembariti, B.S., Frencken, J. E. and Pilot, T. Prevalence and severity of periodontal conditions among adults in urban and rural Morogoro, Tanzania. Community Dent. Oral Epidemiol. 1988; 16: $240-243$.

5. Nyandindi U.S. Oral health habits in the district of Ilala, Tanzania. MSc dissertation, Dar es Salaam: University of Dar es Salaam; 1989. pp 65-71.

6. Sarita, P.T.N. and Tuominen, R. Tooth cleaning methods and their effectiveness among adults in rural Tanzania. Proc. Finn. Dent. Soc. 1992; 88: 139-145.

7. van Palenstein Helderman, W. H., Munck, L., Mushendwa, S. and Mrema, F. G. Cleaning effectiveness of chewing-sticks among Tanzania school children. J. Clin. Periodontol. 1992; 19: 460463.

8. Normak, S. and Mosha, H.J. Relationship between habits and dental health among rural Tanzanian children. Community Dent. Oral Epidemiol. 1989; 17: 317-321.

9. Escheverria, J. J. and Sanz, M. Mechanical supragingival plaque control. In: Lindhe J., Karring T., Lang N.P., editors. Clinical periodontology and implant dentistry. Oxford: Blackwell Munksgaard; 2003. pp 449-463.

10. Swiss Development Cooperation Administration. 2008. (cited 6 Dec 2008). Available at: $h t t: / / w w w$. sdc.admin.ch/en/Home/Countries/Eastern_Central_ Southern_Africa/Tanzania.

11. Pattison, A. M. and Pattison, G. L. Periodontal instrumentation, 2nd edn. California: Appleton \& Lange; 1992. pp 17-18.

12. World Health Organization. Oral health surveys -basic methods, $4^{\text {th }}$ ed. Geneva: World Health Organization; 1997. pp 21-52.

13. Tezel, A., Cariakyi, V., Ciyek, Y. and Demir, T. Evaluation of gingival recession in left-and righthanded adults. Int. J. Neurosci. 2001; 110: 135-146.

14. Kozlowska, M., Wawrzyn-Sobczak, K., Karczewski, J.K. and Sokowska, W. The Oral cavity hygiene as the basic element of the gingival recession prophylaxis. Rocz. Akad. Med. Bialymst. 2005; 50(Suppl 1): 234-237.

15. Albandar, J.M. and Kingman, A. Gingival recession, gingival bleeding, and dental calculus in adults 30 
years of age and older in the United States, 19881994. J. Periodontol. 1999; 70: 30-43.

16. van Palenstein Helderman, W.H., Lembariti, B.S., van der Weijden, G.A. and van't Hof M.A. Gingival recession and its association with calculus in subjects deprived of prophylactic dental care. J. Clin. Periodontol. 1998; 25: 106-111.

17. Vehkalahti, M. Occurrence of gingival recession in adults. J. Periodontol. 1989; 60: 599-603.

18. Baelum, V. and Fejerskov, O. Tooth loss as related to dental caries and periondontal breakdown in adult Tanzanians. Community Dent. Oral Epidemiol. 1986; 14: 353-357.

19. Loe, H., Anerud, A. and Boysen, H. The natural history of periodontal diseases in man: Prevalence, severity and extent of gingival recession. J. Periodontol. 1992; 63: 489-495.

20. Joshipura, K.J., Kent, R.L. and DePaola, P.F. Gingival recession: intra-oral distribution and associated factors. J. Periodontol. 1994; 65: 864-871.

21. Kassab, M.M. and Cohen, R.E. The etiology and prevalence of gingival recession. J. Am. Dent. Assoc. 2003; 134: 220-225.

22. Lang, N.P., Mombeli, A. and Attstrom, R. Dental plaque and calculus. In: Lindhe J., Karring T. and Lang N.P., editors. Clinical periodontology and implant dentistry. Oxford: Blackwell Munksgaard; 2003. pp 81-105.

23. Tanner, A.C., Kent, R. Jr, van Dyke, T., et al. Clinical and other risk indicators for early periodontitis in adults. J. Periodontol. 2005; 76: 573-581.

24. Lindhe J., Karring T. and Lang N.P. Anatomy of the periodontium. In: Lindhe J., Karring T. and Lang N.P, editors. Clinical periodontology and implant dentistry. Oxford: Blackwell Munksgaard; 2003. pp 3-49.

25. Arowojolu M.O. Gingival recession at the University College Hospital, Ibadan prevalence and effect of some aetiological factors. Afr. J. Med. Sci. 2000; 29: 259-263.

26. Susin, C., Haas, A. N., Oppermann, R. V., et al. Gingival recession: epidemiology and risk indicators in a representative urban Brazilian population. $J$. Periodontol. 2004; 75: 1377-1386.

27. Baelum, V. Pattern of periodontal breakdown in adult Tanzanians. Scand. J. Dent. Res. 1987; 95: 221-228.
28. White, D.J. Dental calculus: recent insights into occurrence, formation, prevention, removal and oral health effects of supragingival and subgingival deposits. Eur. J. Oral Sci. 1997; 105: 508-522.

29. Goutoudi, P., Koidis, P.T. and Konstantinidis, A. Gingival recession: a cross-sectional clinical investigation. Eur. J. Prosthodont. Restor. Dent. 1997; 5: 57-61.

30. Mumghamba, E.G.S. and Manji, K.P. Maternal oral health status and preterm low birth weight at Muhimbili National Hospital, Tanzania: a case -control study. BMC Oral Health 2007; 7: 8.

31. Cohen, D.W., Shapiro, J., Friedman, L., Kyle G.C. and Franklin S. A longitudinal investigation of the periodontal changes during pregnancy and fifteen months postpartum. J. Periodontal. 1971; 42: 653657.

32. Tilakaratne, A., Soory, M., Ramasinghe, A.W., et al. Periodontal disease status during pregnancy and 3 months post-partum, in a rural population of SriLankan women. J. Clin. Periodontol. 2000; 27: 787792.

33. Fiorellini, J.P., Kim, D.M. and Ishikawa, S.O. Clinical features of gingivitis. In: Newman M.G., Takei H.H., Klokkevold P.R. and Carranza F.A., editors. Carranza's clinical periodontology. Philadelphia: Saunders, Elsevier; 2006. pp 362-372.

34. Nyandindi U., Palin-Palokas T., Milen A., et al. Participation, willingness and abilities of schoolteachers in oral health education in Tanzania. Community Dent. Health. 1994; 11: 101-104.

35. Khader, Y. S., Rice, J. C. and Lefante, J. J. Factors associated with periodontal diseases in a dental teaching clinic population in northern Jordan. J. Periodontol. 2003; 74: 1610-1617.

36. Rajapakse, P. S., McCracken, G. I., Gwynnett, E., and Heasman, P.A. Does tooth brushing influence the development and progression of non-inflammatory gingival recession? A systematic review. Clin. Periodontal. 2007; 34: 1046-1061.

37. Mandel, I.D. Why pick on teeth? J. Am. Dent. Assoc. 1990; 121: 129-132.

38. Preber, H. and Bergstrom, J. Occurrence of gingival bleeding in smoker and non-smoker patients. Acta Odontol. Scand. 1985; 43: 315-320. 